\title{
Legitimacy and public opinion: a five-step model
}

\author{
Lucas Noyon* (D), Jan W. de Keijser and Jan H. Crijns \\ Institute of Criminal Law and Criminology, Leiden University, The Netherlands \\ ${ }^{\star}$ Corresponding author. E-mail: 1.noyon@law.leidenuniv.nl
}

\begin{abstract}
To date, in Western jurisdictions, many criminal justice reforms are devised and implemented with a close eye on public opinion. These are typically intended to regain or foster legitimacy. However, within this context, there is no common understanding of this concept. This essay aims to provide such a conceptualisation of legitimacy, to enable a consistent and systematic evaluation of attempts to accommodate public opinion. To this end, five levels of legitimacy research are discussed that could structure evaluations of public-opinion-targeted reforms: (1) the normative dimension, (2) the 'audiences' addressed, (3) the purpose of the reforms, (4) trust and distrust, and (5) dialogic, or longitudinal effects. Furthermore, since research departing from these five levels of analysis is likely to result in observations that are, by nature, incommensurable, it is argued that an overall assessment of legitimacy always requires a judgment, rather than mere measurement.
\end{abstract}

Keywords: legitimacy; public opinion; criminal justice

\section{Introduction}

In recent decades, many reforms in Western criminal justice systems are characterised by an increased gravitation towards the voice of the public. These include accommodating public opinion in sentencing (Freiberg and Gelb, 2008a; Ryberg and Roberts, 2014b), political interventions aimed at 'bridging the gap' between established criminal justice practice and moral intuitions of the public (cf. Roberts, 2008) and an increasing engagement of criminal justice professionals in public debates, profiling themselves as a public servant rather than an autonomous expert (Roberts, 2008; Van de Bunt and Van Gelder, 2012).

These reforms usually promise to benefit the legitimacy of criminal justice and are promoted throughout large parts of the criminal justice literature. Many scholars argue that a closer substantive alignment between what the public wants and what criminal justice delivers would increase its moral credibility and consequently its legitimacy (cf. Bibas, 2012; Robinson, 2013; 2014). Others claim that a positioning of criminal justice actors that is more exposed to, and thus can be held accountable by, the tribunal of public opinion would better fit present-day expectations and hence the way in which legitimacy is best 'earned' in contemporary societies (Dzur, 2012; cf. Rosanvallon, 2008).

The ubiquitous usage of the term 'legitimacy' in relation to public-opinion-related reforms does, however, raise new questions about what the concept of legitimacy means in this particular context. At present, there appears to be no common understanding. As a consequence, scholars are prone to vacillating between different conceptions of the term or use the concept of legitimacy within this context rather loosely (cf. Roberts and Plesničar, 2015). This is due to two underlying cleavages in the understanding of legitimacy.

The first is between two approaches of legitimacy within the social sciences: The 'American' conception of legitimacy and the 'étatist-European' understanding of the term (Smith, 2007, p. 30; Tonry, 2007, p. 3). Whereas the first is primarily concerned with perceived procedural justice based on direct dealings with - in particular - the police and the courts, and is by birth rooted in an American 
criminal justice context, the latter is concerned with the public at large that forms its opinions on the basis of vicarious sources and is believed to display particular discontent with substantive justice such as perceived leniency in sentencing (Loader and Sparks, 2013; Smith, 2007). While the latter does prima facie provide a better framework for evaluating public-opinion-oriented reforms, it lacks the operational clarity of the American conception of legitimacy.

A second distinction can be drawn between the normative approach of legitimacy of political philosophy and the empirical approach of the social sciences (cf. Hinsch, 2010; Siems and Nelken, 2017). While these two approaches are clearly distinct, it is becoming increasingly clear that full evaluations of legitimacy need to take both into account (cf. Bottoms and Tankebe, 2012; Jackson and Bradford, 2019; Loader and Sparks, 2013). This is particularly important for the public-opinion-oriented reforms that we are concerned with in this essay, since attempts to count the public in are often regarded as a submission to penal populism or political opportunism (Pratt et al., 2005; Turner, 2014) and therefore considered to be potentially at odds with basic requirements of rational and fair criminal justice. While the threat of engaging in essentially penal-populist activities has been associated with both malign (Lacey, 2008; Zimring et al., 2001) and benign (cf. Ryberg and Roberts, 2014a) attempts to accommodate public opinion in (European) criminal justice systems, this has not yet led to an integrative framework for assessing legitimacy in this context.

The purpose of this essay is to provide a framework of legitimacy with which public-targeted initiatives in criminal justice can be evaluated. To this end, we depart from a 'European' perspective on legitimacy, since we are primarily interested in reforms that are targeted towards the public at large, focusing usually on (media) representations of the criminal justice system (and not on direct experiences) and gravitate towards aspects of substantive, rather than procedural perceptions of justice. Second, we presuppose that this framework cannot be a solely empirical matrix, but instead normative perspectives should be considered as well.

Our framework will consist of a roadmap comprising five levels of analysis that should be addressed when making such an assessment. In short, first, normative dimensions of legitimacy should be mapped. Second, it should be taken into account that criminal justice serves multiple audiences and public-opinion-targeted reforms can have different effects on different audiences. Third, the purpose of legitimacy should be clear: it should be clear whether obedience or something else is pursued. Fourth, a balance should be struck between fostering trust or facilitating distrust. Finally, longitudinal effects should be taken into account.

As following these levels would unavoidably amount to observations that are, by nature, incommensurable, we will argue that an overall assessment of legitimacy effects will always require something more than mere measurement: a judgment in which these findings are weighed and integrated. The framework that is discussed in this essay can serve as a foundation for this judgment by making explicit what is and what is not addressed in a specific research design. This will result in more substantiated and thus more accountable assertions about legitimacy effects of initiatives that seek a closer connection with the public.

\subsection{Overview of the essay}

In the next section, we will briefly introduce three public-opinion-related reforms in criminal justice that have been conceived to improve legitimacy. Those reforms are those that we have in mind when we mention the 'turn to the public' and it is for these developments that we want to design an explicit and elaborate framework to evaluate effects on criminal justice legitimacy. From Section 3 onwards, we will expound on the framework by discussing five levels of analysis that together can provide a systematic understanding of legitimacy in this context. Although these levels are of a conceptual nature, they come with clear implications for how an evaluation of legitimacy should be done. For example, a normative analysis requires a different methodology than is needed for researching the empirical dimensions of legitimacy. And, while some of the empirical dimensions may be best addressed by straightforward quantitative research (like an assessment of trust), others require a more open and 
argumentative analysis. We will touch on these practical questions by concluding each section with a discussion of its 'evaluative implications'. In the final section of this essay, we conclude with a discussion of how disparate findings in conjunction can contribute to a structured assessment of legitimacy.

\section{The turn to the public: three developments in criminal justice}

In recent decades, multiple reforms in criminal justice have taken place that share one characteristic: a close eye on public opinion and an increased willingness to accommodate the voice of the public, at the expense of a more autonomous, professional-oriented system. To illustrate this general point, we will discuss three developments. These examples are all taken from the Dutch jurisdiction but, as we will argue below, represent developments that are also taking place in other - at least other Western - jurisdictions.

A first development is increased interest in public opinion about sentencing. Under Dutch law, sentencing guidelines are developed under direction of the Public Prosecution Service (PPS). In 2006, this institution first stated that its legitimacy would be at stake if prosecutorial guidelines would be too far removed from what the public deemed reasonable (OM, 2006). Subsequently, it has organised citizen fora and conducted Internet surveys in order to accommodate public opinion in sentencing. This marked a break with the past, as these guidelines, like the entire Dutch criminal justice system, used to be the exclusive domain of professionals. Comparable developments have taken place in other countries. Public input in sentencing councils and sentencing policy are flourishing, commonly with a desire to improve legitimacy in mind (see for a discussion of multiple jurisdictions Freiberg and Gelb, 2008a; cf. Roberts and Plesničar, 2015).

A second development is mushrooming political interventions in the criminal justice system, often justified with a felt urge to 'bridge the gap' between what is delivered by established practice and what is demanded by moral intuitions of the public. Within the Dutch criminal law context, the past fifteen years yield ample examples. One such example concerns the imposition of an exclusionary rule for community sentences - a result of societal turmoil following a television documentary (Noyon, 2017). According to Roberts (2008: 18), a similar provision has been imposed in Canada. Other examples from the Dutch jurisdiction include political initiatives to restrict temporary leaves from prison, parole and so forth. Here again, political opportunity for improving austerity at the back end of sentencing appears to be an international phenomenon as well (Lacey, 2008; Roberts, 2008; Zimring et al., 2001). Although one might object that politicians advocating these interventions are not genuinely concerned with improving 'legitimacy' but have first and foremost electoral gain in mind (i.e. the malign, not benign, version of populism), the principal claim accompanying these initiatives is improving legitimacy. Therefore, it seems nothing but fair to evaluate these assertions on their contribution to legitimacy.

A third development is the societal 'positioning' of criminal justice actors. Roberts (2008: 24) discusses the repositioning of criminal justice professionals as 'public servants', instead of autonomous legal experts. The main Dutch example is the PPS. Multiple ethnographic studies (Lindeman, 2017; Van de Bunt, 1985; Van de Bunt and Van Gelder, 2012) have exposed a shift in prime orientation. Traditionally operating as an autonomous legal professional, typically referred to as a 'magistrate', the working ethos of public prosecutors has gradually become that of a civil servant, serving the articulated demands of real-life society rather than what would be required by an abstract legal order. The reorientation towards society came with a new interest in its own reputation, an increased willingness to participate in public debates and an increase in informing society - even during the earliest stages of criminal investigations - in order to meet societal demands for accountability.

\section{Level 1: Normative and empirical dimensions of legitimacy}

\subsection{Core concepts}

The 'turn to the public', as illustrated by the abovementioned developments, seems inspired by a perceived empirical-legitimacy deficit. The assumption is that, if certain adjustments are made, the public 
support, and hence the empirical legitimacy of criminal justice (actors), would be fostered. Legitimacy should, however, not exclusively be conceptualised as an empirical construct. In the classical normative traditions, accounts of legitimacy are commonly construed by reference to - for example - a hypothetical social contract, a principle of utility, a categorical imperative or any other rationalised framework (Merquior, 1980). Hence, the principal entity of orientation is not the real public, with its tempers, passions and irrationalities, but a fictional public comprising legal subjects, marked by rational, consistent and coherent reasoning. The social scientific understanding of legitimacy has only diverged from this branch of scientific inquiry after Max Weber demarcated the work field of the social scientist by asserting that, for him, only a belief in legitimacy (Legitimitätsglaube) should matter (Weber, 2013; cf. Merquior, 1980). Ever since, this value-fact distinction in researching legitimacy has been both defended (Hinsch, 2010) and criticised (Beetham, 2013a; 2013b; Bottoms and Tankebe, 2012; Fossen, 2013; Habermas, 2015).

This criticism did not, however, avert the emergence of two distinct research traditions (cf. Merquior, 1980; Siems and Nelken, 2017). Both agree on a basic definition of legitimacy: the right to rule. But, from there, they diverge. The social scientist is concerned with the recognition of the right to rule by the ruled (Beetham, 2013b; Bottoms and Tankebe, 2012; Jackson et al., 2012; Tyler, 2006). Then, what matters are real opinions, attitudes and behaviour of (members of) the public, from which the 'recognition' can be deduced. Figuratively speaking, legitimacy thus is something that resides in the heads of the people. In contrast, a normatively oriented scholar is not interested in the minds and thoughts of individuals. To him, legitimacy is found elsewhere. In essence, it is an attribute of a power holder or a quality of the relationship between a power holder and its subordinates. It is not about the factual recognition of the rightfulness of power, but about rational standards or principles that serve to defend legitimacy on moral grounds (cf. Beetham, 2013b; Merquior, 1980). The only way to assess legitimacy is, then, by constructing a rational, objectivist and coherent framework, with at its core the rational legal subject that takes part in a social contract, subject to a categorical imperative or to any other imaginative abstract order.

Contemporary accounts of legitimacy in criminal justice are almost all exclusively empirical. Tyler (2006), for example, holds that legitimacy is composed of the trust that people bestow on the (criminal) justice system and the perceived obligation to obey (see further Sunshine and Tyler, 2003; Tyler and Huo, 2002; Tyler and Jackson, 2013). Another leading scholar, Beetham, is not so much concerned with people's evaluations of the current state of affairs, but rather with more abstract notions of what would constitute a legitimate authority. Although Beetham is more interested in the normative considerations on which members of the public base their assessment of legitimacy, he does explicitly put beyond doubt that he is solely interested in the empirical question (Beetham, 2013b, pp. 6-7). Research expanding on Beetham's theoretical work adopts a comparable position (cf. Jackson et al., 2011). Some scholars have tried to bridge the gap between the empirical and normative tradition, by calling into question the possibility of a clear-cut separation (Bottoms and Tankebe, 2012, pp. 157-158), but this has not yet led to concrete research designs.

Normative perspectives do seem particularly relevant, however, for the context at issue in this essay. With regard to sentencing, one of the most important objections against accommodating public opinion concerns the threat of unprincipled, and thus normatively unjust, sentencing (Bagaric, 2014; Roberts, 2014; Roberts and Plesničar, 2015; Ryberg, 2014; Ryberg and Roberts, 2014a; De Keijser, 2014). And an open, dialogic positioning of criminal justice actors in individual criminal cases (the third development discussed in the previous section) may conflict with other fundamental legal principles. Upholding the presumption of innocence, avoiding trial by media and safeguarding only minimal and by-law-prescribed breaches of private life might be hard to reconcile with an ever more informative, dialogue-seeking demeanour of criminal justice actors. Avoiding trial by media may be difficult if the PPS itself fancies exposure to the tribunal of public opinion.

To be sure, transparency is a virtue demanded not only by society. The publicity and transparency requirement, namely the principle of open justice, meaning that criminal proceedings should be open to the public, is a normative principle - just like the presumption of innocence and respect for private 
life are - and as such codified in inter alia Article 6 of the European Convention on Human Rights (ECHR). But, legally, the transparency and publicity requirement have a rather demarcated import, primarily aimed at safeguarding (a) fair trial(s) (see Van Lent, 2008). Moreover, since the normative weighing of conflicting interests does not necessarily coalesce with the upshot of public opinion, it bears a significance of its own.

\subsection{Evaluative implications}

When it comes to evaluating the core concepts described in the previous section, normative-legitimacy research would first require the relevant normative values to be identified. This requires a normative, and not an empirical, type of inquiry. Since the values and norms that are at stake differ depending on the topic at hand, and depend between legal cultures as well, this requires a legal-normative analysis.

We can illustrate this with some examples. For sentencing, a first obvious value is the principle of proportionality. But, depending on the context, other legal principles may come up. If, for example, citizen input in sentencing would result in sentencing policies that discriminate explicitly or implicitly against minorities, the principle of equality comes to the fore. The 'societal positioning' of criminal justice actors provides a good example for the importance of the legal culture of a given society. In some legal cultures (in fact, in most continental-European jurisdictions), providing information about the age and nationality of an arrested suspect is already considered to be at odds with the presumption of innocence. In other jurisdictions, this may be considered entirely uncontroversial. The weighing of the normative principles that are at stake is therefore never a universal enterprise, but always something that should be embedded within local legal custom.

To sum things up: for the first level of assessing the legitimacy of public-opinion-targeted reforms, the normative dimension of legitimacy should be researched with use of classical legal arguments. What these relevant arguments are varies, depending on the nature of the development that is evaluated and the legal culture of that given society.

\section{Level 2: Multiple audiences, macro and micro legitimacy}

\subsection{Core concepts}

When reviewing the existing literature on empirical legitimacy, one remarkable paradox emerges. On the one hand, there is the procedural justice paradigm that has demonstrated convincingly that legitimacy is best earned by optimising procedural justice. This approach advocates a design of criminal proceedings in which interpersonal treatment - treating people with dignity and respect - is of utmost importance. This includes giving voice to - and listening to - people involved (cf. Tyler, 2006). As such, legitimacy would be fostered and this, in turn, would promote all sorts of profitable behaviour, such as compliance, co-operation and obedience. Ultimately, proponents envisage a 'self-regulatory model' when procedural justice would be optimised, in which legitimacy instead of deterrence is the driving force behind lawabiding behaviour (Tyler et al., 2007, p. 11; Tyler and Jackson, 2013, pp. 95-96). As such, repressive law enforcement by criminal justice actors would become a rather peripheral phenomenon.

In more sociological, macro-oriented research, the concept of legitimacy is used in a distinct meaning. Here, authors use the term in relation to the heating-up of public discourse concerning penal questions. As such, the rising-up of a more demotic, punitive sentiment in both political and public debates has given rise to serious concerns about looming legitimacy deficits (Loader and Sparks, 2013; Roberts and Plesničar, 2015). Legitimacy is, within this context, related to punitive sentiments and often associated with a misinformed public that gathers its information about the criminal justice system from vicarious sources and forms its opinion on the basis of often distorted media representations of the criminal justice system (Dzur et al., 2016; Turner, 2018).

Depending on whether one takes the first or second viewpoint as a point of departure, a different set of remedies seems sensible when someone is concerned with a suspected legitimacy deficit. Someone who 
departs from a macro, European perspective might think of accommodating public opinion in sentencing, excluding modes of sentencing (e.g. community service sentences) that have led to public indignation and putting the 'public-servant' ethos of criminal justice professionals first. However, such attempts to appease public discontent almost imperatively implicate an institutionalised, repressive type of law enforcement. Indeed, some interventions that seem to be a fruit of this line of reasoning, such as mandatory minimum sentences and three-strike laws, are antipodal to what is put forward by the procedural justice type of research. Fixed, austere or minimum sentences seem difficult to reconcile with tailored 'procedural just' proceedings with an emphasis on the individual peculiarities of each case and everyone involved.

These diametrically opposed conclusions can be explained by the fact that both perspectives have a different audience in sight. While the first line of research is primarily concerned with people directly involved in criminal proceedings, and thus examines legitimacy at a micro level, the second is interested in the opinion of the public at large (i.e. macro legitimacy). Smith (2007) and Tonry (2007) have labelled the first as the 'American' and the second as the 'European' conception of the term.

The fact that the first conception of legitimacy is rooted in an American legal culture and the second in a European one does not mean that one can or should exclude the 'American' viewpoint of legitimacy from 'European' considerations. Of course, it is clear that, in European jurisdictions, parties involved do benefit from 'procedural just' proceedings (and, vice versa, the heating-up of public discourse is also an American phenomenon). Therefore, it is more useful to learn from this distinction that criminal justice systems have multiple audiences (cf. Bottoms and Tankebe, 2012). Serving the needs of one audience, and promoting the perceived legitimacy here, might have adverse effects on another audience. What serves the macro audience may thwart the possibilities for procedural just proceedings at a micro level. As a consequence, one cannot prefer one approach to legitimacy categorically to the other.

It is important, however, when public-opinion-targeted reforms are taking place with one specific audience in mind to consider the possibility of unintended, adverse (side) effects on other audiences.

\subsection{Evaluative implications}

For judging the 'legitimacy' effects of public-opinion-targeted reforms, it is first and foremost important to distinguish sharply between the two conceptions of legitimacy. Research findings from the procedural justice approach cannot simply be transposed to interventions - such as accommodating public opinion in drafting sentencing guidelines - aimed at legitimacy at a macro level. In any instance, the micro-macro distinction reminds us to bear in mind that findings from one audience cannot simply be transposed to the other. Legitimacy at a micro level is associated with obedience, compliance and co-operation. But it is far from evident whether, and to what extent, macro legitimacy equally incites (these types of) social action. Second, it follows from the above that there is more research to be done concerning possible adverse effects between different types of audience.

There are some other evaluative difficulties concerning the assessment of macro legitimacy that can only be touched upon briefly in this essay. Measuring macro legitimacy is a rather puzzling enterprise. Straightforward, superficial measurements provide a coarse, punitive 'audience', which displays high levels of cynicism about the functioning of criminal justice (cf. Roberts and Hough, 2005). These findings are diametrically opposed to more sophisticated types of public-opinion assessment. It has been shown repeatedly that an informed, deliberative research setting produces a breed of public opinion that is not far removed from established practice (De Keijser, 2014; De Keijser et al., 2006; Indermaur et al., 2012; Indermaur, 2008; Roberts and Hough, 2005; Wagenaar, 2008). Which 'public' would provide the most 'valid' account of public opinion is an as-yet unresolved issue.

\section{Level 3: Defining the purpose of legitimacy}

\subsection{Core concepts}

Since legitimacy is the right to rule, and the empirical dimension of legitimacy is particularly concerned with the empirical recognition of that right by the ruled (see Section 3), any researcher of 
legitimacy should decide how this recognition can be determined: from which reports, observed behaviour, public discourse or other forms of social action this recognition is to be deduced. Is all authority that is generally obeyed by definition legitimate? Or do other non-behavioural types of social action matter as well? Does, for example, displayed discontent with criminal justice performance, or cynicism about sentencing levels, imply a lacking recognition of the right to rule?

Traditionally, major weight in determining the recognition of the right to rule is allotted to obedience. This is perhaps mainly a result of Weber's influence in the social sciences. Bottoms and Tankebe even hold that, for Weber, 'legitimate domination simply is obeyed legality' (2012, p. 130), although this interpretation is contested elsewhere (cf. Hinsch, 2010). Of course, it is important to overcome the simplification to consider all obeyed power legitimate. This may be done by inquiring after a 'perceived obligation to obey' in survey-based research, as has often been done in procedural justice research (Tyler, 2006). The main drawback of this approach is that legitimacy is regarded as something atomic, while the legitimacy problems that seem to fuel the criminal justice reforms that are of prime concern to us are manifest societal phenomena that amount to more than just the sum of individuals' opinions. A second drawback is that typically a small, and predetermined, set of variables is taken into account as possible predictors for legitimacy (cf. Smith, 2007). The value-based nature of legitimacy is hence partially obscured (cf. Bottoms and Tankebe, 2012).

An alternative has been provided by Beetham. He has argued that it is better to ask respondents what they consider to be appropriate standards for legitimate authority in abstracto - leaving it for the researcher to make a comparison between these abstract ideals of a given society and the real-world situation. For Beetham, 'a given power relationship is not legitimate because people believe in its legitimacy, but because it can be justified in terms of their beliefs' (Beetham, 2013b, p. 11, emphasis in original). This approach might provide a richer account of social values that are important to legitimacy - since social values lie at the heart of such an investigation. However, the benefits of such an approach are, by the same token, is drawbacks. When only asking for social values in abstracto, the evaluations of the current state of affairs by members of a given society are rendered irrelevant. This could easily draw attention away from the fact that these evaluations form a force of their own. Examples are the many penal scandals that have led to reforms in criminal justice, while the public and political debate was corrupted with misrepresentations. Empirical legitimacy thus is not only a matter of abstract, shared values. Sudden uprisings, emotionally rather than rationally charged fluctuations and unpredictable dynamics can be a force in themselves that can alter the constitutional or legislative playing field and consequently the parameters of legitimacy.

Therefore, we believe that there is a need to explore some other ways of assessing the 'belief in legitimacy'. We consider it possible to connect research on popular discourse, public denunciation, (surreptitious) disapproval, gossip and so forth to research on legitimacy. This can provide a richer account of normative considerations and hence a more informed account of the recognition of the right to rule. Some promising suggestions include research into (social) media discourse on criminal justice (Prichard et al., 2015). A second step would be to relate this type of inquiry to predictors of legitimacy on the one hand and effects of legitimacy on the other. Whereas the procedural justice approach has demonstrated many of these connections (with procedural justice being the main cause of legitimacy and all kinds of profitable behaviour, some clearly demonstrated effects), these relations have not yet been exposed with regard to this macro, étatist-European level of analysis.

\subsection{Evaluative implications}

A belief in legitimacy can take many forms. With regard to the topic of this essay public-opinion-related reforms in criminal justice - we seek to grasp a belief in legitimacy at a macro level that includes deeper moral intuitions of the public as well as manifest evaluations of the functioning of criminal justice by the public. For the first part, the Beetham model of legitimacy has clear advantages, since it provides a deeper understanding of the mechanisms underlying 
legitimacy. Next to inquiring after these abstract notions, we believe research into public discourse to be best suited. A combined approach can generate the most interesting observations.

\section{Trust and distrust}

\subsection{Core concepts}

A next intriguing dimension of legitimacy revolves around the concepts of trust and distrust. Weber's contemporary Georg Simmel (1958) already maintained that, without trust, any social structure would disintegrate. Expanding on this, researchers have consistently regarded trust to be a constitutive element of legitimacy (cf. Tyler, 2006 and see above). In legitimacy research in less well-known - for example not Western - countries, reported levels of trust are often even equated with legitimacy, perhaps because of limited empirical data (cf. Karstedt, 2013). What appears to be absent in criminal justice literature, however, is the notion that distrust may be equally quintessential to legitimacy. This argument has been advocated in political-science literature (Hardin, 1999; Rosanvallon, 2008) and is worth following within the realm of criminal justice research.

It may sound paradoxical that both trust and distrust can contribute to legitimacy. To explain the point, we need to take a closer look at the ontology of trust. Generally, a definition of trust includes (1) the acceptance of dependency (2) in absence of certainty about the reliability of the power holder (Barbalet, 2009). This definition makes clear that any power holder in any instance will always need a certain amount of trust, as it is impossible for citizens to be completely certain about every aspect of the functioning of a power holder. Hence, the existence of a 'certainty gap' that needs to be bridged by societal trust is always inevitable. But a certainty gap that cannot be bridged because it is too wide or otherwise considered unacceptable by the public does put the criminal justice power holder in a position of a looming empirical-legitimacy deficit.

We can think of two ideal typical modes of how a (criminal justice) power holder might deal with this gap. In the first, it targets the first element of trust and tries to promote its societal acceptability, for example by means of public relations, reputation management and so forth. Underlining responsiveness or a 'tough-on-crime' promise might be strategies in this respect. A second ideal type is aimed at the second element of trust and attempts to inhibit uncertainty. This might be done by being more transparent about the way in which the (criminal justice) authority operates and allowing public oversight. Whereas the first ideal type promotes trust in an absolute sense, because it does not aspire to close the size of the 'certainty gap' itself, but only to make this gap more acceptable, the second ideal type does try to narrow the gap. As such, the term 'facilitating distrust' might be a more appropriate term for this second ideal type, as it encourages citizens to scrutinise government performances. Both ideal types do of course not exist in real-life society in a 'pure' form. But criminal justice actors can, in their attempts to legitimise themselves, gravitate towards the first or the second ideal type.

It is this appreciation of distrust that we believe should not be overlooked in legitimacy research, first because of the (normative) consideration that legitimate authority is based on a conditional delegation of rights and conferral of power of an individual to the government (e.g. by means of a social contract), which implies the need for some vigilance among subordinates, next to some accountability of the power holder; and, second, because of what Rosanvallon (2008) has coined the emergence of 'an age of distrust'. He argues that, in contemporary Western societies, citizens are more inclined than before to exercise vigilance, oversight and denunciation, while power holders have adapted to this new reality by being more accountable and exposing themselves more to the tribunal of public opinion. Indeed, the reforms that we described in the second section seem to fit this description of Rosanvallon.

Researching distrust requires a different perspective than researching trust. 'Trust' may be higher or lower and is often even expressed in quantitative terms. For distrust, however, it appears to be too easy to simply assume that (quantitative) levels of distrust affect legitimacy. Even Rosanvallon, a profound protagonist of the appreciation of distrust as a legitimacy-enriching factor, acknowledges that there is one 'pathological' manifestation of distrust: populism (2008, pp. 265-273). What seems crucial for any 
fruitful exercise of distrust is its quality. If distrust is an expression of commitment, and an ambition to scrutinise government in order to inhibit uncertainty, it can maturate legitimacy. But it is more difficult to see how cynical, ill-founded distrust, albeit considered an expression of commitment, can improve legitimacy.

A next observation about distrust follows from the previous. As the quality of distrust demands something from the public, it is clear that mechanisms of distrust are essentially dialogic. A power holder can facilitate distrust by being more transparent, but what is needed from the public is some civic engagement to exercise distrust genuinely: a willingness to close the certainty gap rather than rushing into denunciation. There is perhaps less sense in being more transparent if the public is more into 'compulsive and permanent stigmatization of the ruling authorities' instead of 'an active, positive urge to inspect what the government is doing' (cf. Rosanvallon, 2008, p. 268).

\subsection{Evaluative implications}

The complex interplay between trust and distrust calls for different evaluative questions. First, it might be interesting to investigate whether criminal justice actors gravitate towards the first ideal type or towards the second. The developments discussed in the second section provide interesting research cases. Citizen fora might be organised primarily to foster acceptance - for example because they come with a promise of responsiveness - but can also be organised to facilitate distrust, for example because these fora are deployed to inform citizens and provide them with an opportunity for oversight. And participating in public debates might be done to gain acceptance (perhaps by means of bold language) but can also serve as a means to be held accountable and, as such, provide the public with an opportunity to narrow the certainty gap.

Other questions concern the public. Here, levels of trust remain of interest. But just as interesting would be the quality (or temper) of distrust. Although the nature of distrust seems something that should be better explored in criminal justice research, we can think of at least three ideal typical categories in advance. A first is non-existent distrust, meaning an absence of societal commitment. Next to this, it appears sensible to distinguish between two ideal typical modes of distrust that do depart from some level of societal commitment: radicalised displays of distrust, leading to the compulsive denunciation that Rosanvallon has coined as archetypically populist; and constructive, vigilant distrust. Again, 'pure' ideal types are a mere theoretical option and it would be interesting to research the dominant currents within the public.

A final theme questions how the positioning and demeanour of the criminal justice power holder relates to the type(s) of distrust that can be found among the public. It questions whether what the power holder is doing is well aligned with what is expected by the public. Since these 'dialogic' aspects of distrust mechanisms are closely related to the final level of legitimacy research that is discussed in the next section, we will elaborate on this there.

\section{Longitudinal - or dialogic - nature of legitimacy}

\subsection{Core concepts}

One of the more recent contributions to the literature on legitimacy was added by Bottoms and Tankebe; they propose a 'dialogic approach' (2012; 2013). Their principle objection against some preexisting conceptualisations (such as the Beetham model) is that they can easily lead to 'hypostatization' (Bottoms and Tankebe, 2013, p. 66). Bottoms and Tankebe warn against thinking of legitimacy as a fixed or static quality and thereby overlooking the interactive and unpredictable nature (cf. Fossen, 2013; Loader and Sparks, 2013; Martin and Bradford, 2019). Central to the dialogic approach to legitimacy is that longitudinal effects should be taken into account. Their remarks about the dynamic nature fit well the observations that we made in previous sections. For both the relation between 
abstract notions and manifest recognition (Section 5) and the dialogic praxis of distrust (Section 6), we concluded with remarks about the importance of claim/response sequences.

Numerous other longitudinal effects can be thought of. Because of the inherently unpredictable and interactive nature of these effects, it is undoable to anticipate them in advance. But, regarding the developments discussed in the second section, lessons about (unintended) (side) effects can be learned from history. Attempts to close the gap between actual sentencing levels and what is demanded by the public (see the first development in Section 2) seem to be an insurmountable enterprise, since people are notoriously ill-informed about factual levels of sentencing, and factual-sentencing practice and the percentage of people who are dissatisfied with perceived practice seem unrelated (De Keijser, 2014; Freiberg and Gelb, 2008b; Roberts and De Keijser, 2014; Roberts and Hough, 2005). Although general levels of sentencing have gone up in recent decades, a robust proportion of society maintains that sentences are generally too low (Cullen et al., 2000; Gelb, 2008, pp. 72-73; Hindelang, 1974, p. 106; Hough and Roberts, 1999; Pratt, 2008, p. 32; Sprott and Doob, 1997).

Political interventions that are a fruit of penal scandals (see the second development in Section 2), such as exclusionary rules for community sentencing and mandatory minimum sentences, have often suffered from significant unintended (side) effects. Research has shown that mandatory minimum sentences are often bypassed by the judiciary (Van Kalmthout and Tak, 2003). This may be leading to renewed public indignation, as these bypasses could easily spark new penal scandals. Long-term legitimacy effects of the public-debate engagement of criminal justice professionals (the third development) seem to be a relatively underexplored topic. Interesting research questions include whether this repositioning is welcomed by the public and to what extent the attitude deployed (e.g. fostering trust or facilitating distrust) is in line with public preferences (see Section 6.1). Other interesting questions are concerned with (unintended) effects. Does, for example, a horizontal repositioning promote public vigilance? Does it cause the public to assume that their opinion matters?

\subsection{Evaluative implications}

We have discussed several possible methods of assessing longitudinal or dialogic effects already in previous sections. Here, we can add to this that, given the lens that longitudinal effects offer for assessing unintended or unpredictable effects, case-studies seem a useful tool to comprehensively assess effects of the several initiatives that seek a closer connection to the public. Since dynamic effects are by nature unpredictable, it seems most promising to start with some exploratory, qualitative research. Case-studies using, for example, participant observational research methods seem suitable for carefully analysing reforms like the new 'positioning' of criminal justice actors.

Apart from considering the 'dialogic nature' of legitimacy as one aspect - of five - of legitimacy, we can also think of the dialogic approach as an overarching framework for studying legitimacy. Case-studies could, apart from being a tool to assess longitudinal effects, also function as a research design that accommodates all the levels of analysis that we presented in previous sections. Moreover, the metaphor of a dialogue could also serve as a useful perspective from which to view legitimacy as a whole: just like dialogues in everyday life, public-opinion-oriented reforms can be a fruit of emotions and misunderstandings, but also a sincere and calm attempt at better understanding. Looking at this from a 'dialogic' perspective might provide a profitable viewpoint.

\section{Conclusion: judging legitimacy of the turn to the public}

In previous sections, we have argued that, while a lot of criminal justice reforms are taking place with a close eye on the public and with improving 'legitimacy' in mind, to date, no clear conceptualisation of legitimacy exists that fits this specific context. This has led to rather unsatisfactory unsubstantiated claims about possible legitimacy effects of these reforms. To make legitimacy scientifically tangible in this specific context, we have argued that it is best to structure legitimacy research by addressing five levels of analysis. 
We believe that this model offers advantages in comparison with two ways in which the concept of legitimacy is used in criminal justice literature. First, there are prevailing accounts of legitimacy developed in psychology (cf. Tyler, 2006), some infused with political-science perspectives (cf. Jackson et al., 2011). These conceptualisations are elaborate and operationally refined, but tend to view legitimacy as an atomic instead of a societal phenomenon, focusing on direct dealings that people have with the police or the courts and - as a consequence - on aspects of procedural justice. As such, we believe that these models do not provide a perfect fit with criminal justice reforms that are designed to appease public opinion, since these initiatives are typically targeted at meeting the demands of the public at large: demands that are formed on the basis of vicarious (indirect) sources and are usually more about substantive - instead of procedural - justice. The second branch of legitimacy studies does not provide a solid alternative, however. Here, we see that the notion of legitimacy is used rather loosely, in such a way that it is unclear whether it is anything more than an opinion or to what extent the use of the word 'legitimacy' adds anything to a mere positive personal evaluation of some development or situation.

Applying the five levels set out in this essay offers a middle road. We believe that legitimacy is best conceptualised as a reasoned judgment based on the collective evaluation of the five levels discerned. A valid account of legitimacy will always require more than only measurement. Any research operationalisation (whether or not departing from the levels discussed) requires multiple choices, such as whether to include or exclude the normative dimension and/or longitudinal effects or which modes of recognition are considered important and which audiences are researched. These choices can be made for theoretical, practical and organisational reasons. But, if legitimacy research is not simplified to just one dimension or audience - and we hope to have demonstrated in this essay that there are good reasons not to - it will often produce findings that are by nature incommensurable. And there appears to be no objective way to alchemise, for example, an assessment of normative values, research into the quality of distrust and/or research into abstract values into one assertion about legitimacy.

Viewing legitimacy as a reasoned judgment provides a solid alternative in between the specific - but reductionist and perhaps less well fitting - models and the rather loose and vague ways in which the concept of legitimacy is used elsewhere. The five-level framework can help in structuring and substantiating such a reasoned judgment: first, by exposing the choices that are (implicitly) made in any research design; second, by viewing legitimacy as a judgment that is reasoned instead of an only measured entity, disparate research findings become useful building blocks instead of obnoxious incommensurabilities; and, finally, as this model helps in identifying relevant building blocks, it can guide how to weigh research findings and how to put them in the context of other findings and possible missing information. In this way, an evaluation of legitimacy effects becomes a narrative in which the relevant research findings are appraised and considered in light of what has not been part of a certain research project. One might object that a reasoned judgment will always remain inherently subjective. But, by being transparent about the building blocks and the weight that is allotted to each, a legitimacy judgment can be buttressed that is structured and substantiated.

Conflicts of Interest. None

Acknowledgements. None

\section{References}

Bagaric M (2014) Proportionality in sentencing: the need to factor in community experience, not public opinion. In Ryberg J and Roberts JV (eds), Popular Punishment: On the Normative Significance of Public Opinion. Oxford: Oxford University Press.

Barbalet J (2009) A characterization of trust, and its consequences. Theory and Society 38, 367-382.

Beetham D (2013a) Revisiting legitimacy. twenty years on. In Tankebe J and Liebling A (eds), Legitimacy and Criminal Justice: An International Exploration. Oxford: Oxford University Press, pp. 19-36.

Beetham D (2013b) The Legitimation of Power, 2nd edn. Basingstoke: Palgrave Macmillan.

Bibas S (2012) The Machinery of Criminal Justice. Oxford: Oxford University Press. 
Bottoms A and Tankebe J (2012) Beyond procedural justice: a dialogic approach to legitimacy in criminal justice. Journal of Criminal Law and Criminology 102, 119-170.

Bottoms A and Tankebe J (2013) 'A voice within': power-holders' perspectives on authority and legitimacy. In: Tankebe J and Liebling A (eds), Legitimacy and Criminal Justice: An International Exploration. Oxford: Oxford University Press, pp. $60-82$.

Cullen FT, Fisher BS and Applegate BK (2000) Public opinion about punishment and corrections. Crime and Justice 27, $1-79$.

De Keijser JW (2014) Penal theory and popular opinion: the deficiencies of direct engagement. In Ryberg J and Roberts JV (eds), Popular Punishment: On the Normative Significance of Public Opinion. New York: Oxford University Press, pp. 101-118.

De Keijser JW, Van Koppen PJ and Elffers H (2006) Op de stoel van de rechter: Oordeelt het publiek net zoals de strafrechter? Den Haag: Raad voor de rechtspraak.

Dzur AW (2012) Punishment, Participatory Democracy \& the Jury. New York: Oxford University Press.

Dzur AW, Loader I and Sparks R (2016) Punishment and democratic theory: resources for a better penal politics. In Dzur AW, Loader I and Sparks R (eds), Democratic Theory and Mass Incarceration. New York: Oxford University Press, pp. 1-17.

Fossen T (2013) Taking stances, contesting commitments: political legitimacy and the pragmatic turn. Journal of Political Philosophy 21, 426-450.

Freiberg A and Gelb K (2008a) Penal Populism, Sentencing Councils and Sentencing Policy. Collumpton: Willan.

Freiberg A and Gelb K (2008b) Penal populism, sentencing councils and sentencing policy. In Freiberg A and Gelb K (eds), Penal Populism, Sentencing Councils and Sentencing Policy. London/New York: Routledge, pp. 1-14.

Gelb K (2008) Myths and misconceptions: public opinion versus public judgment about sentencing. In Freiberg A and Gelb K (eds), Federal Sentencing Reporter. Oxon: Willan Publishing, pp. 68-82.

Habermas J (2015) Between Facts and Norms: Contributions to a Discourse Theory of Law and Democracy. Cambridge/ Malden: Polity Press.

Hardin R (1999) Do we want trust in government. In Warren ME (ed.), Democracy \& Trust. Cambridge: Cambridge University Press, pp. 22-41.

Hindelang MJ (1974) Public opinion regarding crime, criminal justice, and related topics. Journal of Research in Crime and Delinquency 11, 101-116.

Hinsch W (2010) Justice, legitimacy, and constitutional rights. Critical Review of International Social and Political Philosophy 13, 39-54.

Hough M and Roberts JV (1999) Sentencing trends in Britain: public knowledge and public opinion. Punishment \& Society 1, 11-26.

Indermaur D (2008) Dealing the public in: challenges for a transparent and accountable sentencing policy. In Freiberg A and Gelb K (eds), Penal Populism, Sentencing Councils and Sentencing Policy. London/New York: Routledge, pp. 45-67.

Indermaur D et al. (2012) A matter of judgement: the effect of information and deliberation on public attitudes to punishment. Punishment \& Society 14, 147-165.

Jackson J and Bradford B (2019) Blurring the distinction between empirical and normative legitimacy? A methodological commentary on 'Police legitimacy and citizen cooperation in China'. Asian Journal of Criminology 14, 265-289.

Jackson J et al. (2011) Developing European indicators of trust in justice. European Journal of Criminology 8, $267-285$.

Jackson J et al. (2012) Why do people comply with the law? Legitimacy and the influence of legal institutions. British Journal of Criminology 52, 1051-1071.

Karstedt S (2013) Trusting authorities: legitimacy, trust and collaboration in non-democratic regimes. In Tankebe J and Liebling A (eds), Legitimacy and Criminal Justice: An International Exploration. Oxford: Oxford University Press, pp. 127-156.

Lacey N (2008) The Prisonners' Dilemma: Political Economy and Punishment in Contemporary Democracies. New York: Cambridge University Press.

Lindeman JMW (2017) Officieren van justitie in de 21e eeuw: Een verslag van participerend observatieonderzoek naar de taakopvatting en taakinvulling van officieren van justitie. Den Haag: Boom Juridische Uitgevers.

Loader I and Sparks R (2013) Unfinished business: legitimacy, crime control, and democratic politics. In Tankebe J and Liebling A (eds), Legitimacy and Criminal Justice: An International Exploration. Oxford: Oxford University Press, pp. 105-126.

Martin R and Bradford B (2019) The anatomy of police legitimacy: dialogue, power and procedural justice. Theoretical Criminology 0, 1-19.

Merquior JG (1980) Rousseau and Weber: Two Studies in the Theory of Legitimacy. London/Boston/Henley: Routledge \& Kegan Paul.

Noyon L (2017) De geschiedenis van het 'taakstraf-verbod' van artikel 22b Sr: een klucht vol verwarring. Ars Aequi 4, $307-315$. OM (2006) Perspectief op 2010. Den Haag: OM.

Pratt J (2008) Penal scandal in New Zealand. In Freiberg A and Gelb K (eds), Penal Populism, Sentencing Councils and Sentencing Policy. London/New York: Routledge, pp. 31-44.

Pratt J et al. (2005) The New Punitiveness: Trends, Theories, Perspectives. Cullompton: Willan Publishing. 
Prichard J et al. (2015) Social media sentiment analysis: a new empirical tool for assessing public opinion on crime? Current Issues in Criminal Justice 27, 217-236.

Roberts JV (2008) Sentencing policy and practice: the evolving role of public opinion. In Freiberg A and Gelb K (eds), Penal Populism, Sentencing Councils and Sentencing Policy. London/New York: Routledge, pp. 15-30.

Roberts JV (2014) Clarifying the significance of public opinion for sentencing policy and practice. In Ryberg J and Roberts JV (eds), Popular Punishment: On the Normative Significance of Public Opinion. New York: Oxford University Press, pp. 228-252.

Roberts JV and De Keijser JW (2014) Democratising punishment: sentencing, community views and values. Punishment \& Society 16, 474-498.

Roberts JV and Hough M (2005) Understanding Public Attitudes to Criminal Justice. Maidenhead: Open University Press.

Roberts JV and Plesničar MM (2015) Sentencing, legitimacy, and public opinion. In Meško G and Tankebe J (eds), Trust and Legitimacy in Criminal Justice: European Perspectives. Cham/Heidelberg/New York/Dordrecht/London: Springer, pp. 33-51.

Robinson PH (2013) Intuitions of Justice and the Utility of Desert. New York: Oxford University Press.

Robinson PH (2014) The proper role of community in determining criminal liability and punishment. In Ryberg J and Roberts JV (eds), Popular Punishment: On the Normative Significance of Public Opinion. New York: Oxford University Press, pp. 54-75.

Rosanvallon P (2008) Counter Democracy: Politics in an Age of Distrust. Cambridge: Cambridge University Press.

Ryberg J (2014) Penal theory, moral intuitions and public opinion. In Ryberg J and Roberts JV (eds), Popular Punishment: On the Normative Significance of Public Opinion. New York: Oxford University Press, pp. 14-32.

Ryberg J and Roberts JV (2014a) Introduction: Exploring the normative significance of public opinion for state punishment. In Ryberg J and Roberts JV (eds), Popular Punishment: On the Normative Significance of Public Opinion. New York: Oxford University Press, pp. 1-13.

Ryberg J and Roberts JV (2014b) Popular Punishment: On the Normative Significance of Public Opinion. New York: Oxford University Press.

Siems M and Nelken D (2017) Global social indicators and the concept of legitimacy. International Journal of Law in Context 13, 436-449.

Simmel G (1958) Philosophie des Geldes. Berlin: Duncker \& Humblot.

Smith DJ (2007) The foundations of legitimacy. In Tyler TR (ed.), Legitimacy and Criminal Justice. New York: Russell Sage Foundation, pp. 30-58.

Sprott JB and Doob AN (1997) Fear, victimization, and attitudes to sentencing, the courts, and the police. Canadian Journal of Criminology 39, 275-291.

Sunshine J and Tyler TR (2003) The role of procedural justice and legitimacy in shaping public support for policing. Law and Society Review 37, 513-548.

Tonry M (2007) Preface. In Tyler TR (ed.), Legitimacy and Criminal Justice: International Perspectives. New York: Russell Sage Foundation, pp. 3-8.

Turner ER (2018) Public Confidence in Criminal Justice: A History and Critique. Cham: Palgrave Macmillan.

Turner L (2014) Penal populism, deliberative methods, and the production of 'public opinion' on crime and punishment. The Good Society 23, 87-102.

Tyler TR (2006) Why People Obey the Law. Princeton: Princeton University Press.

Tyler TR and Huo YJ (2002) Trust in the Law: Encouraging Public Cooperation with the Police and Courts. New York: Russell Sage Foundation.

Tyler TR and Jackson J (2013) Future challanges in the study of legitimacy and criminal justice. In Tankebe J and Liebling A (eds), Legitimacy and Criminal Justice: An International Exploration. Oxford: Oxford University Press, pp. 83-104.

Tyler TR et al. (2007) Legitimacy and criminal justice: international perspectives. In Tyler TR (ed.), Legitimacy and Criminal Justice: International Perspectives. New York: Russell Sage Foundation, pp. 9-29.

Van de Bunt HG (1985) Officieren van justitie: Verslag van een participerend observatieonderzoek. Zwolle: Tjeenk Willink.

Van de Bunt HG and Van Gelder J-L (2012) The Dutch Prosecution Service. Crime and Justice 41, 117-140.

Van Kalmthout AM and Tak PJP (2003) Ups en downs van de minimumstraf: een verkennende studie naar het voorkomen van minimumstraffen in Frankrijk, België, Duitsland, Engeland en Wales. Nijmegen: Wolf Legal Publishers.

Van Lent L (2008) Externe openbaarheid in het strafproces. Den Haag: BJU.

Wagenaar WA (2008) Strafrechtelijke oordelen van rechters en leken. Den Haag: Sdu.

Weber M (2013) Economy and Society, Vol. 1. Berkeley/Los Angeles/London: University of California Press.

Zimring FE, Hawkins G and Kamin S (2001) Punishment and Democracy: Three Strikes and You're Out in California. Oxford/New York: Oxford University Press.

Cite this article: Noyon L, de Keijser JW, Crijns JH (2020). Legitimacy and public opinion: a five-step model. International Journal of Law in Context 16, 390-402. https://doi.org/10.1017/S1744552320000403 